\title{
A descriptive study of vitamin $D$ and other nutritional factors in breast cancer patients in Saudi Arabia
}

\author{
Nora A. AlFaris, MS, PhD, Nora M. ALkehayez, MS, PhD, Fatema I. Almushawah, MD,SCHS-GS, \\ AbdulRhman N. Al Naeem, MD, PhD, Nadia D. AL-Amri, MD, PhD, Ebtisam S. Almudawah, MD, PhD.
}

\begin{abstract}
الهدف: تقييم دور مستوى فيتامين (د ) في السيرم والعوامل

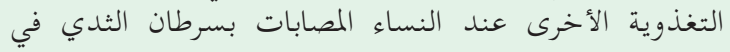
السعودية.

الطريقة: تم أختيار500 امرأة تتراوح أعمارهن بين 250 و 60 سنة 60 سنة

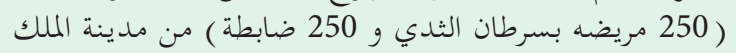

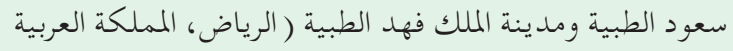

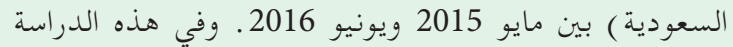

المقطعية تم تقدير ضغط الدمم، وتركيز فيتامين (د ود في في البلازما

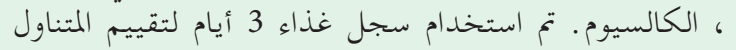

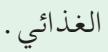

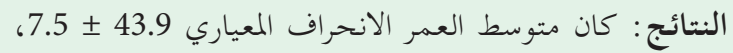

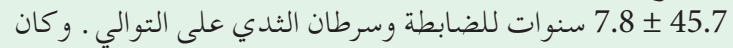

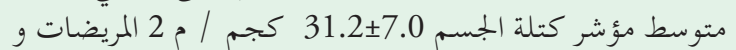

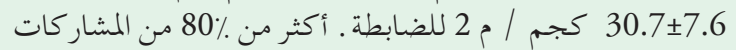

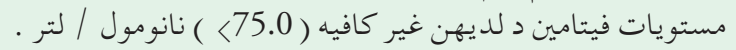

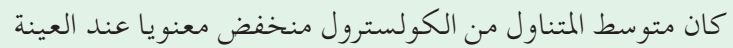

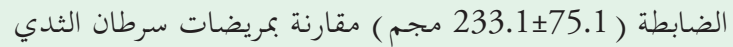

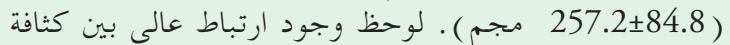

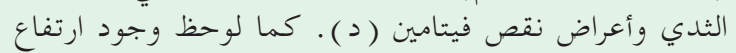

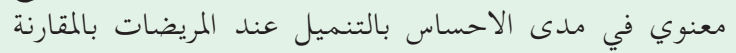

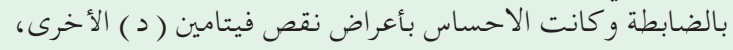

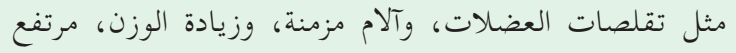

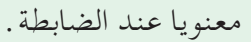

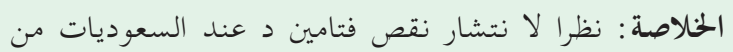

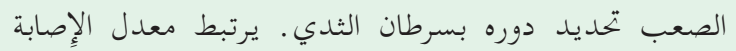

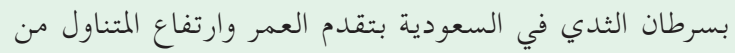

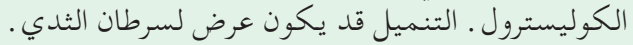

Objectives: To assess the role of serum vitamin $\mathrm{D}$ and other nutritional factors in women with breast cancer in Saudi.
Methods: A total of 500 women (250 patients with breast cancer and 250 controls) aged 30-60 years were recruited from King Saud Medical City and King Fahad Medical City, Riyadh, Saudi Arabia, between May 2015 and June 2016. In this cross-sectional study, blood pressure, plasma concentrations of vitamin D, and calcium levels were evaluated. A 3-day dietary record was used to assess dietary intake.

Results: The mean body mass index was $31.2 \pm 7.0$ $\mathrm{kg} / \mathrm{m}^{2}$ for the breast cancer group and $30.7 \pm 7.6$ $\mathrm{kg} / \mathrm{m}^{2}$ for the control group. More than $80 \%$ of the participants had insufficient vitamin D levels $(<75.0 \mathrm{nmol} / \mathrm{L})$. The mean cholesterol intake was significantly $(p=0.001)$ lower in the control group $(233.1 \pm 75.1 \mathrm{mg})$ than in the breast cancer group $(257.2 \pm 84.8 \mathrm{mg})$. Breast density was found to be significantly associated with vitamin $\mathrm{D}$ deficiencysymptoms. Severe paresthesia was also significantly associated with breast cancer. The incidence of other vitamin D deficiency-symptoms was significantly higher in the control group.

Conclusion: Due to prevalence of vitamin D deficiency in Saudi Arabia, it is difficult to determine the relationship to breast cancer. The incidence of it is associated with old age and high cholesterol intake, and paresthesia may be a symptom of breast cancer.

Saudi Med J 2018; Vol. 39 (6): 564-571

doi: 10.15537/smj.2018.6.21902

From the Nutrition and Food Science (AlFaris, ALkehayez), Princess Nourah bint Abdulrahman University, from the Department of Surgical Oncology (ALMushawah), from the Medical Imaging Administration, Women's Imaging Department (Al Naeem), King Fahad Medical City; and from the Department of Radiology (AL-Amri), from the Day Surgery Unit (Almudawah), King Saud Medical City, Riyadh, Kingdom of Saudi Arabia

Received 31st January 2018. Accepted 16th May 2018.

Address correspondence and reprint request to: Dr. Nora $A$. AlFaris, Nutrition and Food Science, Princess Nourah bint Abdulrahman University, Riyadh, Kingdom of Saudi Arabia. E-mail: naalfaris@pnu.edu.sa

ORCID ID: orcid.org/0000-0002-9135-5725 
B reast cancer is a major cause of cancer-related death and has been identified as a public health issue worldwide. ${ }^{1}$ This cancer type accounts for $25.8 \%$ of all newly diagnosed cancer cases among women and was the most diagnosed malignancy in 2012 in Saudi Arabia. ${ }^{2} \mathrm{Al}-\mathrm{Amri}$ et $\mathrm{al}^{3}$ reported that breast cancer is the most commonly diagnosed malignancy among women in Saudi Arabia, and the Saudi Cancer Registry has recently revealed a consistent increase in the incidence of breast cancer in Saudi Arabian women in recent years. ${ }^{2}$ Moreover, the incidence and mortality rates of breast cancer has reportedly increased not only in high-income countries like Saudi Arabia, but also in low- to middle-income countries. ${ }^{4}$

Many factors such as population growth, aging, lifestyle changes, poor nutrition, lack of physical activity, and urbanization play potential roles in the pathophysiology of breast cancer. ${ }^{4-7}$ Moreover, age at menarche, age at menopause, and family history of a first-degree relative with breast cancer are substantiated risk factors for breast cancer. ${ }^{8,9}$

Epidemiological studies have supported a link between low serum 25-hydroxyvitamin D $(25[\mathrm{OH}] \mathrm{D})$ concentrations and adverse health conditions in the general population. ${ }^{10,11}$ Vitamin $\mathrm{D}$ deficiency and insufficiency are common health problems in the Middle East including Saudi Arabia, where this deficiency or insufficiency has been reported in $81 \%$ of different populations. ${ }^{12}$ In Saudi Arabia, more than $30 \%$ of young healthy women are reported to be vitamin $\mathrm{D}$ deficient despite the presence of high UV sunlight throughout the year. ${ }^{13,14}$ While many studies have focused on the relationship between vitamin $\mathrm{D}$ and the incidence of breast cancer, only a few have investigated the potential relationship between serum $25(\mathrm{OH}) \mathrm{D}$ status and cancer survival. ${ }^{15}$ Vitamin $\mathrm{D}$ plays a role in reducing the risk of many cancer types, including those of the breast, stomach, colon, and prostate. ${ }^{16}$ Several experimental studies have also confirmed the role of vitamin $\mathrm{D}$ in reducing the risk of breast cancer. ${ }^{17,18}$ Vitamin D, has been shown to regulate the expression of genes regulating cell proliferation, differentiation, and apoptosis via its receptor in the mammary tissue. ${ }^{19}$ Wong et al, ${ }^{20}$ found an increased

Disclosure. Authors have no conflict of interests, and the work was not supported or funded by any drug company. This study was funded by the King Abdulaziz City for Science and Technology, Riyadh, Saudi Arabia (AT-34-50) risk of cancer-related death among women with serum $25(\mathrm{OH}) \mathrm{D}$ concentrations of less than $64.0 \mathrm{nmol} / \mathrm{L}$, though they did not report an increase in cancer incidence per se.

Therefore, this study aimed to assess the prevalence of vitamin D deficiency and other potentially important risk factors, such as lifestyle factors, dietary intake, and socioeconomic factors, in patients with newly diagnosed breast cancer and compare this data with that obtained from healthy controls. Our findings may help identify the potential risk factors that may have contributed to the increase in the incidence of breast cancer in Saudi Arabia; further, our findings may guide the implementation of methods for the early detection of vitamin $\mathrm{D}$ deficiency in clinical practice and aid in appropriate management for improving the health outcomes of low-resource patients.

Methods. Study design and participants. Previously, the focus was primarily on the prevalence of vitamin $\mathrm{D}$ deficiency in cancer patients. The aim of this study is to find the role of nutrients and socioeconomic characteristics in patients newly diagnosed with breast cancer and in comparison to a control group of women without breast cancer.

A total of 500 women were recruited from King Saud Medical City $(n=159)$ and from King Fahad Medical City $(n=341)$ (Riyadh, Saudi Arabia) between May 2015 and June 2016 based on the following inclusion criteria: age 20-60 years, living in Saudi Arabia, and with no prior diagnosis of any medical disorder that interferes with the vitamin D status (such as thyroid disease). Patients with a history of any type of cancer were excluded. A cross-sectional study design was used to evaluate serum levels of vitamin D and other nutritional factors associated with risk of breast cancer among those who visited the surgical clinic at King Saud Medical City and King Fahad Medical City, Riyadh, Saudi Arabia for follow-up examinations. Of the 500 included women, 250 were newly diagnosed with breast cancer and were included in the breast cancer group, while the remaining 250 had no prior history of any type of cancer and were included in the control group.

All study participants provided informed written consent in their native language prior to enrollment. This study was conducted according to the principles of the Helsinki Declaration, and the study design was approved by the Institutional Review Boards of King Saud Medical City and King Fahad Medical City (Riyadh, Saudi Arabia). Breast density was measured using mammography and was classified into 4 categories: low, mild, moderate, and high. ${ }^{21}$ 
Data collection. Sociodemographic characteristics, including age at marriage, educational level, occupation, monthly income, sun exposure, and parity was collected using a questionnaire. Dietary data were also collected, and included information regarding the consumption of foods containing vitamin D, such as fish, yogurt, and cheese. Details such as types and amounts of food, preparation methods, and serving size of each item were collected by asking the participants to recall what they had consumed within a 3-day period (24-hour dietary recall) retrospective. Daily intake of vitamin $D$ for each participant was estimated by using Food Processor for Windows (version 7.71; ESHA Research, Inc., Salem, OR, USA). A daily vitamin D intake of a minimum of $600 \mathrm{IU}(15.0 \mu \mathrm{g})$ was considered adequate based on the dietary reference intakes for women. ${ }^{22}$

To measure plasma vitamin $\mathrm{D}$ levels, blood samples were collected after a 12-hours fasting period. The samples were centrifuged at 2,000 rpm for 20 minutes to separate the plasma, which was then stored at $-70^{\circ} \mathrm{C}$ for later analysis. Roche Elecsys vitamin D3 assay (Roche Diagnostics GmbH, Mannheim, Germany), using a Cobas e601 immunoassay analyzer was used to estimate plasma vitamin D3 levels. Measured vitamin $\mathrm{D}$ levels were then classified as sufficient $(>75.0$ $\mathrm{nmol} / \mathrm{L}$ ), insufficient $(50.0-75.0 \mathrm{nmol} / \mathrm{L})$, or deficient $(<50.0 \mathrm{nmol} / \mathrm{L}){ }^{23}$

Statistical analyses. Continuous variables are presented as mean $\pm \mathrm{SD}$, while categorical variables are presented as frequencies and percentages. Participants were categorized according to vitamin $\mathrm{D}$ status and differences between variables were evaluated using the Student's t-test (for comparing variables between 2 groups) or the analysis of variance method (for comparing variables among 3 or more groups). The Chi-square test was used to analyze the relationship between 2 categories (variables). Statistical Package for the Social Sciences for Windows, software version 20.0 (IBM Corp., Armonk, NY, USA) was used for all statistical analyses. Statistical significance was defined as $p<0.05 .{ }^{24}$

Results. The baseline characteristics of the participants (age, body weight, body mass index [BMI], blood pressure, plasma vitamin D and calcium levels, vitamin $\mathrm{D}$ and calcium intake and supplementation, and percentage of recommended dietary intake) are presented in Table 1 . The mean age \pm SD in the overall cohort was $40.4 \pm 11.0$ years. The average BMI indicated obesity, with the mean BMI being $30.7 \pm 7.6$ $\mathrm{kg} / \mathrm{m}^{2}$ in the control group versus $31.2 \pm 7.0 \mathrm{~kg} / \mathrm{m}^{2}$ in the breast cancer group. Systolic blood pressure was high in both groups at $135.0 \pm 13.0$ in the breast cancer group and $133.0 \pm 14.0 \mathrm{~mm} \mathrm{Hg}$ in the control group. By contrast, diastolic blood pressure was within normal limits. The mean vitamin D concentration of the entire study population indicated insufficiency, with $57.4 \%$ of women classified as vitamin D deficient. In

Table 1 - Baseline characteristics of all study participants ( $N=500)$.

\begin{tabular}{|c|c|c|c|}
\hline \multirow{2}{*}{ Characteristic } & \multicolumn{2}{|c|}{ Participants } & \multirow[t]{2}{*}{$P$-value } \\
\hline & $\begin{array}{l}\text { Control } \\
(\mathbf{n}=250)\end{array}$ & $\begin{array}{c}\text { Breast cancer } \\
(\mathrm{n}=250)\end{array}$ & \\
\hline Age (years), mean $\pm \mathrm{SD}$ & $43.9 \pm 7.5$ & $45.7 \pm 7.8$ & $0.011^{*}$ \\
\hline Weight $(\mathrm{kg})$, mean \pm SD & $75.5 \pm 17.0$ & $77.0 \pm 15.6$ & 0.302 \\
\hline $\begin{array}{l}\text { Body mass index }\left(\mathrm{kg} / \mathrm{m}^{2}\right) \text {, mean } \pm S D \\
\text { Normal: } 18.5-25 \\
\text { Obese: } 30-35\end{array}$ & $30.7 \pm 7.6$ & $31.2 \pm 7.0$ & 0.514 \\
\hline $\begin{array}{l}\mathrm{SBP}(\mathrm{mmHg}) \text {, mean } \pm \mathrm{SD} \\
\text { Normal: } 120\end{array}$ & $133.0 \pm 14.0$ & $135.0 \pm 13.0$ & 0.093 \\
\hline $\mathrm{DBP}(\mathrm{mmHg})$, mean $\pm \mathrm{SD}$ & $72.8 \pm 13.1$ & $71.7 \pm 9.9$ & 0.306 \\
\hline Vitamin $\mathrm{D}(\mathrm{nmol} / \mathrm{L})$, mean $\pm \mathrm{SD}$ & $52.8 \pm 32.4$ & $49.7 \pm 31.0$ & 0.307 \\
\hline $\begin{array}{l}\text { Vitamin D, } n(\%) \\
\text { Deficient }(<50.0 \mathrm{nmol} / \mathrm{L}) \\
\text { Insufficient }(50.0-75 \mathrm{nmol} / \mathrm{L}) \\
\text { Sufficient }(>75.0 \mathrm{nmol} / \mathrm{L})\end{array}$ & $\begin{array}{r}140(28.0) \\
55(11.0) \\
55(11.0)\end{array}$ & $\begin{array}{r}147(29.4) \\
52(10.4) \\
51(10.2)\end{array}$ & 0.816 \\
\hline Calcium $(\mathrm{mmol} / \mathrm{L})$, mean $\pm \mathrm{SD}$ & $2.3 \pm 0.1$ & $2.3 \pm 0.5$ & 0.188 \\
\hline Vitamin D supplement, n (\%) & $121(48.4)$ & $130(52.0)$ & 0.421 \\
\hline Calcium supplement, n (\%) & $66(26.4)$ & $68(27.2)$ & 0.840 \\
\hline Age at menopause (years), mean \pm SD & $46.6 \pm 6.4$ & $48.7 \pm 5.2$ & $0.022^{*}$ \\
\hline Age at menarche (years), mean $\pm S D$ & $13.0 \pm 1.9$ & $12.9 \pm 1.8$ & 0.610 \\
\hline
\end{tabular}


addition, the data showed that there was no relationship between breast cancer diagnosis and blood vitamin D levels ( $p=0.816$ ). Moreover, $>80 \%$ of the patients with breast cancer and the controls had insufficient vitamin D levels $(<75.0 \mathrm{nmol} / \mathrm{L})$. Approximately $50 \%$ of the participants reported taking vitamin D supplements, and $>25 \%$ reported taking calcium supplements. The mean \pm SD age at menarche was $13.0 \pm 1.9$ years in the control group and $12.9 \pm 1.8$ years in the breast cancer group. The mean \pm SD age at menopause was lower in the control group $(46.6 \pm 6.4$ years) than that in the breast cancer group ( $48.7 \pm 5.2$ years) (Table 1$)$.

As shown in Table 2, $40.8 \%$ of the patients with breast cancer and $35.4 \%$ of the controls were married. The proportion of participants who were married was significantly lower in the control group than that in the breast cancer group, and the proportion of participants who were married at age $\leq 18$ years was higher in the breast cancer group than that in the control group $(20 \%$ versus $18.9 \%$ ). The proportions of the participants who were married at age 18-30 years were similar between the control group and breast cancer group $(28.4 \%$ and $28.9 \%$ ). More than $70 \%$ of the participants (36\% of the controls and $37.6 \%$ of the patients with breast cancer) had $>3$ children. Table 2 shows that most patients with breast cancer $(27.4 \%)$ had a low income. By contrast, the proportions of participants with low, moderate, and high income in the control group were higher than those of participants in the breast cancer group. The proportion of participants in the control group who attained a university level education was higher (18.4\%) than that of the patients with breast cancer (12.6\%), although most participants in both groups had a low education status.

As shown in Table 3, a low proportion of patients with breast cancer $(22.4 \%)$ was exposed to sunlight. Of those who were exposed to sunlight, the exposure in most controls (37.4\%) and patients with breast cancer $(37.9 \%)$ was before $10: 00$ am and between 10:00 am and 3:00 pm, with 29\% of patients with breast cancer being exposed to sunlight for $>15$ minutes daily compared to $22.9 \%$ in controls. The sites of exposure were mainly hands and face devoid of sun block. As shown in Table 3, more than two-thirds of the participants (68\%) did not do any sport, and $67.8 \%$ of the participants who played a sport did not identify the location at which the sport was played. The proportion of participants who practiced sports was lower in the breast cancer group than that in the control group.

Table 2 - Socioeconomic characteristics of all study participants ( $N=500)$.

\begin{tabular}{|c|c|c|c|c|}
\hline \multirow[t]{2}{*}{ Characteristic } & \multicolumn{2}{|c|}{ Participants } & \multirow[t]{2}{*}{ Total } & \multirow{2}{*}{$P$-value } \\
\hline & $\begin{array}{l}\text { Control } \\
(\mathrm{n}=250)\end{array}$ & $\begin{array}{c}\text { Breast cancer } \\
(\mathbf{n}=250)\end{array}$ & & \\
\hline Marital status, $n(\%)$ & & & & $0.034^{*}$ \\
\hline Married & $177(35.4)$ & $204(40.8)$ & $381(76.2)$ & \\
\hline Single & $26(5.2)$ & $13(2.6)$ & $39(7.8)$ & \\
\hline Divorced & $27 \quad(5.4)$ & $19(3.8)$ & $46 \quad(9.2)$ & \\
\hline Widowed & $20 \quad(4.0)$ & $14 \quad(2.8)$ & $34 \quad(6.8)$ & \\
\hline Age at marriage (years), mean $\pm S D$ & & & & 0.409 \\
\hline$\leq 18$ & $87(18.9)$ & $92(20.0)$ & $179(38.8)$ & \\
\hline $18-30$ & $131(28.4)$ & $133(28.9)$ & $264(57.3)$ & \\
\hline$>30$ & $6(1.3)$ & $12(2.6)$ & $13(2.8)$ & \\
\hline Number of children, $n$ (\%) & & & & 0.719 \\
\hline$\leq 3$ & $54(12.4)$ & $61(14.0)$ & $115(26.4)$ & \\
\hline$>3$ & $157(36.0)$ & $164(37.6)$ & $321(73.6)$ & \\
\hline Duration of breast feeding (months), $n$ (\%) & & & & 0.065 \\
\hline$\leq 6$ & $87(20.9)$ & $75(18.0)$ & $162(39.0)$ & \\
\hline $7-11$ & $33(7.93)$ & $24 \quad(5.8)$ & $57(13.7)$ & \\
\hline $12-24$ & $78(18.6)$ & $106(25.5)$ & $184(44.2)$ & \\
\hline Did not breast feed & 8 (1.9) & $5(1.2)$ & $13(3.1)$ & \\
\hline Income (SR), $n(\%)$ & & & & $0.015^{*}$ \\
\hline Low $<4,000$ & $141(28.2)$ & $169(33.8)$ & $310(62.0)$ & \\
\hline Middle 4,001-10,000 & $71(14.0)$ & $45(9.0)$ & $116(23.2)$ & \\
\hline High $>10,000$ & $38(7.6)$ & $36 \quad(7.2)$ & $74(14.8)$ & \\
\hline Education, $n$ (\%) & & & & $0.005^{*}$ \\
\hline Below high school & $158(31.6)$ & $187(37.4)$ & $345(69.0)$ & \\
\hline High school or above & $92(18.4)$ & $63(12.6)$ & $155(31.0)$ & \\
\hline${ }^{*} p<0.05$ (Chi-sq & $\begin{array}{l}\text { orical data; } \\
\text { Riyal (US\$1. }\end{array}$ & $\begin{array}{l}\text { t's t-test for co } \\
75 \text { SR). }\end{array}$ & uous data) & \\
\hline
\end{tabular}


The mean \pm SD daily intake of vitamin D was similar between the control group (304.8 \pm $129.75)$ and the breast cancer group $(307.1 \pm 143.3)$ (Figure 1). Both groups received approximately 50\% of their recommended daily intake of vitamin D (recommended daily intake of vitamin D for women, 600 IU). The highest mean intake of vitamin D was from dairy products, followed by animal protein, fat, and oil sources. The lowest mean intake of vitamin D was from vegetable and fruit sources (Figure 1).

Table 3 - Lifestyle factors assessed in all study participants $(\mathrm{N}=500)$.

\begin{tabular}{|c|c|c|c|}
\hline \multirow[t]{2}{*}{ Factor } & \multicolumn{2}{|c|}{ Participants } & \multirow[t]{2}{*}{$P$-value } \\
\hline & $\begin{array}{l}\text { Control } \\
(\mathrm{n}=250)\end{array}$ & $\begin{array}{l}\text { Breast cancer } \\
\quad(\mathrm{n}=250)\end{array}$ & \\
\hline Exposed to sunlight & $102(20.4)$ & $112(22.4)$ & 0.816 \\
\hline $\begin{array}{l}\text { Period of exposure } \\
\text { Before 10:00 am } \\
\text { After 10:00 am }\end{array}$ & $\begin{array}{l}80(37.4) \\
22(10.2)\end{array}$ & $\begin{array}{r}81(37.85) \\
31(14.5)\end{array}$ & 0.642 \\
\hline $\begin{array}{l}\text { Long exposure (minu } \\
\quad<15 \\
\quad>15\end{array}$ & $\begin{array}{l}53(24.8) \\
49(22.9)\end{array}$ & $\begin{array}{l}51(23.8) \\
61(28.5)\end{array}$ & 0.642 \\
\hline $\begin{array}{l}\text { Part of the body expo } \\
\text { Face and hands } \\
\text { Other } \\
\text { Uses sun block } \\
\text { Plays sport }\end{array}$ & $\begin{array}{l}78(36.5) \\
24(11.2) \\
43(8.6) \\
87(17.4)\end{array}$ & $\begin{array}{l}87(40.7) \\
25(11.7) \\
35 \quad(7.0) \\
64(12.8)\end{array}$ & $\begin{array}{l}0.065 \\
0.197 \\
0.170\end{array}$ \\
\hline $\begin{array}{l}\text { Place of sport } \\
\text { Outdoor } \\
\text { Indoor }\end{array}$ & $\begin{array}{l}55(39.0) \\
32(22.7)\end{array}$ & $\begin{array}{l}34(24.1) \\
20(14.2)\end{array}$ & $0.022^{*}$ \\
\hline $\begin{array}{l}\text { Duration of sport (bc } \\
\quad<1 \\
\quad \geq 1\end{array}$ & $\begin{array}{c}84(59.6) \\
3 \quad(2.1)\end{array}$ & $\begin{array}{r}50(35.5) \\
4 \quad(2.8)\end{array}$ & 0.080 \\
\hline $\begin{array}{r}\text { Values are } \\
{ }^{*} p<0.05 \text { (Chi-squ } \\
\end{array}$ & $\begin{array}{l}\text { sed as numbe } \\
\text { t for categori } \\
\text { continuous d }\end{array}$ & $\begin{array}{l}\text { and percentage } \\
\text { l data; Studen } \\
\text { a) }\end{array}$ & est for \\
\hline
\end{tabular}
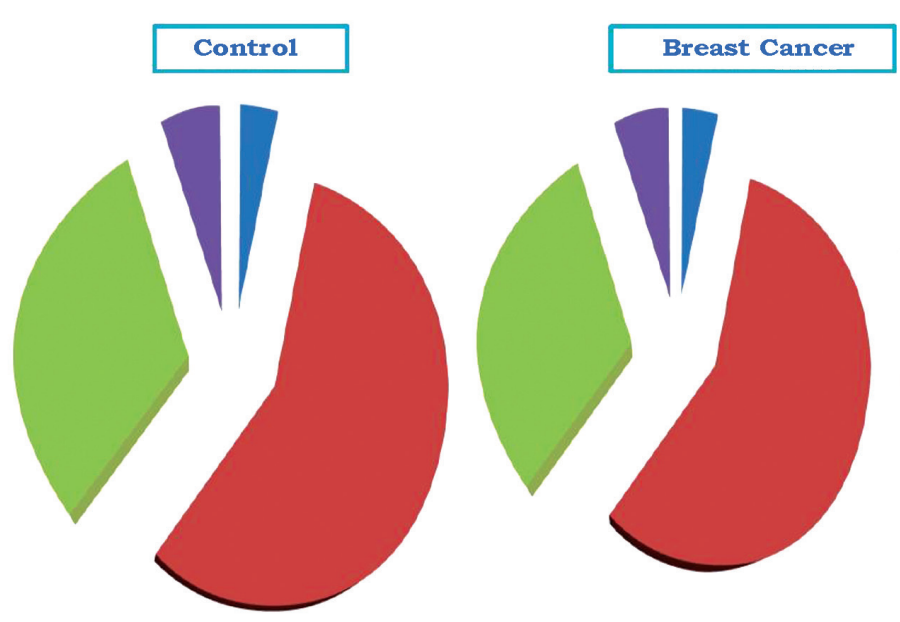

Vegetables and Fruits (IU/D)

Dairy products (IU/D)

Meat, Fish and

Poultry products (IU/D)

Fats and Oils (IU/D)

Figure 1 - Sources of vitamin D (IU/D) intake from 4 groups. 
Vitamin D in breast cancer ... AlFaris et al

Table 5 - Association between breast density and symptoms of vitamin D deficiency

\begin{tabular}{|c|c|c|c|c|c|c|}
\hline \multirow{2}{*}{$\begin{array}{l}\text { Vitamin D } \\
\text { deficiency symptom }\end{array}$} & \multicolumn{4}{|c|}{ Breast density $\mathbf{n}(\%)$} & \multirow[t]{2}{*}{ Total } & \multirow[t]{2}{*}{ P-value } \\
\hline & Low & Mild & Moderate & High & & \\
\hline Severe paresthesia & & & & & & $0.028^{\circ}$ \\
\hline Control & $18 \quad(9.4)$ & $22(11.5)$ & $17 \quad(8.9)$ & $15(7.8)$ & $82(42.7)$ & - \\
\hline Breast cancer & $13(6.8)$ & $53(27.6)$ & $33(17.2)$ & $11 \quad(5.7)$ & $110(57.3)$ & - \\
\hline Total & $31(16.1)$ & $75(39.1)$ & $60(31.3)$ & $26(13.5)$ & $192(100.0)$ & \\
\hline Joint pain & & & & & & $0.001^{\circ}$ \\
\hline Control & $31 \quad(9.4)$ & $48(14.6)$ & $55(16.7)$ & 32 (9.7) & $166(50.5)$ & \\
\hline Breast cancer & $19 \quad(5.8)$ & $74(22.5)$ & $50(15.2)$ & $20 \quad(6.1)$ & $163(49.5)$ & - \\
\hline Total & $50(15.2)$ & $122(37.1)$ & $105(31.9)$ & $52(15.8)$ & $329(100.0)$ & - \\
\hline Chronic pain & & & & & & $0.007^{\circ}$ \\
\hline Control & $15(23.8)$ & $8(12.7)$ & $12(19.1)$ & $6(9.5)$ & $41(65.1)$ & - \\
\hline Breast cancer & $6 \quad(9.5)$ & $3(4.8)$ & $10(15.9)$ & $3(4.8)$ & $22(34.9)$ & - \\
\hline Total & $21(33.3)$ & $11(17.5)$ & $22(34.9)$ & $9(14.3)$ & $63(100.0)$ & \\
\hline Increased weight & & & & & & $0.004^{\circ}$ \\
\hline Control & $15(15.2)$ & $12(12.1)$ & $19(19.2)$ & $14(14.1)$ & $60(60.6)$ & \\
\hline Breast cancer & $9 \quad(9.1)$ & $19(19.2)$ & $9(9.1)$ & $2(2.0)$ & $39(39.4)$ & - \\
\hline Total & $24(24.2)$ & $31(31.3)$ & $28(28.3)$ & $16(16.2)$ & $99(100.0)$ & - \\
\hline
\end{tabular}

of calcium and vitamins E, D, and B12 were higher in the control group than that in the breast cancer group.

As shown in Table 5, breast density was significantly related with symptoms of vitamin D deficiency. A highly significant relationship between breast density and paresthesia was also observed $(p<0.01)$. Mild breast density was the most significant contributing factor for severe paresthesia, with $39.1 \%$ of participants having a mild breast density. A highly significant relationship was also observed between mild breast density and joint pain. Moderate to low breast density was more significantly related with chronic pain than high breast density. Data also revealed a significant relationship between breast density and increased weight.

As shown in Table 5, the breast density in the control group correlated significantly with muscle cramps, chronic pain, and increased weight $(p<0.01)$. Breast density was also found to be more significantly associated with severe paresthesia in the breast cancer group than in the control group.

Discussion. The mean age of patients with breast cancer was significantly higher than of the controls $(p<0.05)$. However, the mean age of these patients in the current study was 5-10 years lower than that reported in the Saudi Cancer Registry ${ }^{25}$ and the study by $\mathrm{Al}$ Mulhim et al. ${ }^{26}$ In addition to age, the World Health Organization, ${ }^{27}$ also reported that other factors associated with breast cancer risk include late age at marriage, early menarche, late menopause, and long menstrual history. Our findings revealed a later age at menopause in patients with breast cancer than in controls, which is in line with previous findings. ${ }^{27}$

The results showed that the majority of patients with breast cancer had low income and educational level. By contrast, the control group had higher proportions of all categories for income and educational attainment compared to those in the breast cancer group. The higher educational status of the control group may reflect better knowledge of healthy dietary habits and awareness of risk of diseases such as breast cancer associated with poor diet. In connection to this, the incidence of breast cancer has been increasing in low- to middle-income countries. This increase is assumed to be caused by a combination of factors, such as population growth, lifestyle changes, aging, obesity, family history of malignancy, genetics, and delivering the first child after age 30 years. ${ }^{5,27,28}$

Several studies have focused on the role of nutrients in breast cancer development and progression. ${ }^{29,30}$ It has been reported that breast cancer risk may be affected by specific dietary components and differences in dietary habits. ${ }^{31}$ A positive relationship between increased daily total fat consumption and risk of breast cancer has been proposed. ${ }^{32}$ According to Freedman et $\mathrm{al}^{33}$ and Mobarakeh et al, ${ }^{34}$ increased fat intake significantly affects the carcinogenesis pathway in mammary cells, and healthy dietary plans may be an appropriate strategy for breast cancer prevention. In the present study, differences in fat intake between the control group and breast cancer group were minimal and statistically insignificant, precluding an analysis of 
the role of dietary fat in increasing the risk of breast cancer. The consumption of cholesterol in our study was significantly higher in the breast cancer group than that in the control group, which supports the findings of several previous studies, reporting high blood cholesterol as a risk factor for breast cancer. ${ }^{35,36}$ Moreover, the aggressiveness of breast tumors and disease progression have been reported to be linked to high plasma cholesterol levels. ${ }^{29}$

While some reports have implied a potential role for Vitamin D in the prevention of breast cancer, our data was not in agreement with this contention. In this study, there was no significant difference in the vitamin $\mathrm{D}$ levels between the breast cancer group and the control group. Though a majority of patients with breast cancer had insufficient levels of vitamin D, this observation may be attributed to the high prevalence of vitamin $\mathrm{D}$ deficiency and insufficiency in the general population in Saudi Arabia. ${ }^{37,38}$ However, Formiga et $\mathrm{al}^{39}$ revealed in an observational study that low levels of $25(\mathrm{OH}) \mathrm{D}$ may be linked to several types of breast cancer. In contrast, epidemiological evidence suggests an inverse relationship between vitamin D deficiency and adverse health outcomes. ${ }^{40}$ Our data showed significant associations between breast density and several symptoms of vitamin D deficiency. Women with mild to moderate breast density were more likely to develop symptoms of vitamin D deficiency, such as severe paresthesia, joint pain, and increased weight. Except for paresthesia, these symptoms were more noticeable in the control group than in the breast cancer group. Women with a low to moderate breast density were more likely to have chronic pain. McCullough et $\mathrm{al}^{41}$ indicated that high breast tissue density was a major risk factor for breast cancer. Al Mulhim et $\mathrm{al}^{26}$ reported that the majority of patients with breast cancer had high breast density. Taken together, these findings imply that paresthesia may be one of the symptoms of breast cancer.

One limitation of this study; however, is that only information concerning vitamin $\mathrm{D}$ and calcium levels at one time point was available, and no information regarding exposure to sunlight across different seasons was provided. Another limitation is that plasma cholesterol levels were not measured, warranting further studies.

We evaluated the effect of education status, economic status, and vitamin D sufficiency on breast cancer risk in Saudi Arabian women. We additionally sought to identify possible predictive factors that may aid in disease detection. Our findings may help future studies to identify risk factors and develop recommendations for maintaining healthy dietary and lifestyle patterns that will aid in disease prevention.

In conclusion, our findings highlight significant factors that may contribute to the risk of breast cancer. We show that low income, low education level, and high cholesterol intake are associated with increased risk of breast cancer. Thus, health policies focusing on the importance of the factors affecting women's health should be established to educate women and to prevent breast cancer. Information concerning women in Saudi Arabia may guide members of the health care team in implementing methods for the early detection of risk factors for breast cancer in clinical practice and aid in providing appropriate management tools to improve health outcomes in low-income patients.

Acknowledgment. Authors would like to thank the King Abdulaziz City for Science and Technology (KACST), Riyadh, Saudi Arabia, for the financial assistance provided to conduct this research. Authors would like to thank Editage (www.editage.com) for English language editing.

\section{References}

1. Torre LA, Bray F, Siegel RL, Ferlay J, Lortet-Tieulent J, Jemal A. Global cancer statistics, 2012. CA Cancer J Clin 2015; 65: 87-108.

2. Bazarbashi S, Al Eid H, Minguet J. Cancer Incidence in Saudi Arabia: 2012 Data from the Saudi Cancer Registry. Asian Pac J Cancer Prev 2017; 18: 2437-2344.

3. Al-Amri FA, Saeedi MY, Al-Tahan FM, Ali AM, Alomary SA, Arafa $\mathrm{M}$, et al. Breast cancer correlates in a cohort of breast screening program participants in Riyadh, KSA. J Egypt Natl Canc Inst 2015; 27: 77-82.

4. Torre LA, Siegel RL, Ward EM, Jemal A. Global Cancer Incidence and Mortality Rates and Trends--An Update. Cancer Epidemiol Biomarkers Prev 2016; 25: 16-27.

5. DeSantis CE, Bray F, Ferlay J, Lortet-Tieulent J, Anderson $\mathrm{BO}$, Jemal A. International variation in female breast cancer incidence and mortality rates. Cancer Epidemiol Biomarkers Prev 2015; 24: 1495-1506.

6. Shapira N. The potential contribution of dietary factors to breast cancer prevention. Eur J Cancer Prev 2017; 26: 385-395.

7. Catsburg C, Miller AB, Rohan TE. Adherence to cancer prevention guidelines and risk of breast cancer. Int J Cancer 2014; 135: 2444-2452.

8. Howell A, Anderson AS, Clarke RB, Duffy SW, Evans DG, Garcia-Closas $M$, et al. Risk determination and prevention of breast cancer. Breast Cancer Res 2014; 16: 446.

9. Torre LA, Islami F, Siegel RL, Ward EM, Jemal A. Global cancer in women: Burden and trends. Cancer Epidemiol Biomarkers Prev 2017; 26: 444-457.

10. Arnson Y, Gringauz I, Itzhaky D, Amital H. Vitamin D deficiency is associated with poor outcomes and increased mortality in severely ill patients. QJM 2012; 105: 633-639.

11. Fan C, Nieto FJ, Bautista LE, Fine JP. Vitamin D intake and cardiovascular mortality in the NHANES I epidemiological follow-up study cohort. J Diet Suppl 2012; 9: 79-89. 
12. Al-Daghri NM. Vitamin D in Saudi Arabia: Prevalence,distribution and disease associations. J Steroid Biochem Mol Biol 2018; 175: 102-107.

13. Al-Turki HA, Sadat-Ali M, Al-Elq AH, Al-Mulhim FA, Al-Ali AK. 25-Hydoxyvitamin D levels among healthy Saudi Arabian women. Saudi Med J 2008; 29: 1765-1768.

14. El-Kaissi S, Sherbeeni S. Vitamin D deficiency in the Middle East and its health consequences for adults. In: Holick MF, editor. Vitamin D: Physiology, Molecular Biology, and Clinical Applications. 2nd ed. New York (NY): Humana Press; 2010. p. 495-503.

15. Villase-or A, Ballard-Barbash R, Ambs A, Bernstein L, Baumgartner K, Baumgartner R, et al. Associations of serum 25-hydroxyvitamin $\mathrm{D}$ with overall and breast cancer-specific mortality in a multiethnic cohort of breast cancer survivors. Cancer Causes Control 2013; 24: 759-767.

16. Cheney CP, Thorand B, Huth C, Berger K, Peters A, Seifert-Klauss $\mathrm{V}$, et al. The Association between serum 25-Hydroxyvitamin D and cancer risk: Results from the prospective KORA F4 Study. Oncol Res Treat 2018; 41: 117-121.

17. Welsh J, Wietzke JA, Zinser GM, Byrne B, Smith K, Narvaez CJ. Vitamin D-3 receptor as a target for breast cancer prevention. $J$ Nutr 2003; 133 (7 Suppl): 2425S-2433S.

18. Bertone-Johnson ER, Chen WY, Holick MF, Hollis BW, Colditz GA, Willett WC, et al. Plasma 25-hydroxyvitamin D and 1,25-dihydroxyvitamin D and risk of breast cancer. Cancer Epidemiol Biomarkers Prev 2005; 14: 1991-1997.

19. Welsh J. Vitamin D and breast cancer: insights from animal models. Am J Clin Nutr 2004; 80 (6 Suppl): 1721S-1724S.

20. Wong G, Lim WH, Lewis J, Craig JC, Turner R, Zhu K, et al. Vitamin D and cancer mortality in elderly women. BMC Cancer 2015; 15: 106.

21. Vachon CM, van Gils CH, Sellers TA, Ghosh K, Pruthi S, Brandt KR, et al. Mammographic density, breast cancer risk and risk prediction. Breast Cancer Res 2007; 9: 217.

22. Ross AC, Taylor CL, Yaktine AL, Del Valle HB, editors. Dietary Reference Intakes for Calcium and Vitamin D. Washington (DC): National Academies Press; 2011.

23. Holick MF, Binkley NC, Bischoff-Ferrari HA, Gordon CM, Hanley DA, Heaney RP, et al.; Endocrine Society. Evaluation, treatment, and prevention of vitamin D deficiency: an Endocrine Society clinical practice guideline. J Clin Endocrinol Metab 2011; 96: 1911-1930.

24. Larson R, Farber B. Elementary Statistics: Picturing the World. 5 Ed. Upper Saddle River (NJ): Prentice-Hall; 2012.

25. Saudi Cancer Registry. Saudi Arabia Cancer Incidence Report 2012. Riyadh, Saudi Arabia: Saudi Cancer Registry, 2015. [Accessed December 2017]. Available from: http://www.chs.gov. sa/Ar/HealthRecords/CancerRegistry/CancerRegistryReports/
26. Al Mulhim FA, Syed A, Bagatadah WA, Al Muhanna AF. Breast cancer screening programme: experience from Eastern province, Saudi Arabia. East Mediterr Health J 2015; 21: 111-119.

27. World Health Organization. Breast cancer: prevention and control. Geneva: World Health Organization; 2018. [Accessed 2018]. Available from: http://www.chs.gov.sa/Ar/ HealthRecords/CancerRegistry/CancerRegistryReports/" http://www.who.int/cancer/detection/s/

28. Beiler JS, Zhu K, Hunter S, Payne-Wilks K, Roland CL, Chinchilli VM. A case-control study of menstrual factors in relation to breast cancer risk in African-American women. $J$ Natl Med Assoc 2003; 95: 930-938.

29. Llaverias G, Danilo C, Mercier I, Daumer K, Capozza F, Williams TM, et al. Role of cholesterol in the development and progression of breast cancer. Am J Pathol 2011; 178: 402-412.

30. Shapira N. The potential contribution of dietary factors to breast cancer prevention. Eur J Cancer Prev 2017; 26: 385-395.

31. Moorman PG, Terry PD. Consumption of dairy products and the risk of breast cancer: a review of the literature. Am J Clin Nutr 2004; 80: 5-14.

32. Howe GR, Hirohata T, Hislop TG, Iscovich JM, Yuan JM, Katsouyanni K, et al. Dietary factors and risk of breast cancer: combined analysis of 12 case-control studies. J Natl Cancer Inst 1990; 82: 561-569.

33. Freedman LS, Clifford C, Messina M. Analysis of dietary fat, calories, body weight, and the development of mammary tumors in rats and mice: a review. Cancer Res 1990; 50: 5710-5719.

34. Mobarakeh ZS, Mirzaei K, Hatmi N, Ebrahimi M, Dabiran S, Sotoudeh G. Dietary habits contributing to breast cancer risk among Iranian women. Asian Pac J Cancer Prev 2014; 15: 9543-9547.

35. Furberg AS, Veierød MB, Wilsgaard T, Bernstein L, Thune I. Serum high-density lipoprotein cholesterol, metabolic profile, and breast cancer risk. J Natl Cancer Inst 2004; 96: 1152-1160.

36. Ferraroni M, Gerber M, Decarli A, Richardson S, Marubini E, Crastes de Paulet P, et al. HDL-cholesterol and breast cancer: a joint study in northern Italy and southern France. Int J Epidemiol 1993; 22: 772-780.

37. Al-Mogbel ES. Vitamin D status among Adult Saudi Females visiting Primary Health Care Clinics. Int J Health Sci 2012; 6: 116-126.

38. Alsuwadia AO, Farag YM, Al Sayyari AA, Mousa DH, Alhejaili FF, Al-Harbi AS, et al. Prevalence of vitamin D deficiency in Saudi adults. Saudi Med J 2013; 34: 814-818.

39. Formiga F, Ferrer A, Megido MJ, Boix L, Contra A, Pujol R. Octabaix study members. Low serum vitamin D is not associated with an increase in mortality in oldest old subjects: the Octabaix three-year follow-up study. Gerontology 2014; 60: 10-15.

40. Fan C, Nieto FJ, Bautista LE, Fine Jp, (2012). Vitamin D intake and cardiovascular mortality in the NHANES 1 epidemiological follow-up study cohort. J Dietary Supplements 2012; 9: 79-89.

41. McCullough ML, Stevens VL, Patel R, Jacobs EJ, Bain EB, Horst RL, et al. Serum 25-hydroxyvitamin D concentrations and postmenopausal breast cancer risk: a nested case control study in the Cancer Prevention Study-II Nutrition Cohort. Breast Cancer Res 2009; 11: R64. 